\title{
The Role of Resilience in Coping with Negative Parental Behaviour
}

\section{Silvia Barnová - Viola Tamášová - Slávka Krásna*}

Received: June 20, 2019; received in revised form: July 5, 2019; accepted: July 6, 2019

\begin{abstract}
:
Introduction: Negative parental behaviour is among the significant risk factors that can have a negative impact on an individual's development. In certain contexts, when appropriate protective factors are available, individuals deal with adversity better and it does not come to a decrease in their social performance nor their achievement in various spheres of life.

Purpose: The purpose of the presented paper is to provide a literature review on the role of resilience in dealing with harsh circumstances when negative parental behaviour occurs in a family.

Methods: In the study, the traditional desk research method was used to gather data.

Conclusions: Exposure to negative parental behaviour - including abuse and neglect, as well as domestic violence, can have detrimental consequences for children's health and welfare. Under such circumstances, protective factors available to children play a significant role. Exposure to negative parental behaviour, including abuse and neglect, as well as domestic violence, can have detrimental consequences for children's health and welfare. Under such circumstances, protective factors available to children play a significant role. If a family fails to protect a child or even represents a risk factor in the child's life, the importance of other social institutions, such as schools, church, peer groups, etc., increases, as both internal and external protective factors are important. They can provide children at risk with support, help them develop own coping strategies and foster their resilience in order to overcome significant adversity in their families without serious harm. An individual's resilience is a decisive factor in the process of dealing with threatening situations.
\end{abstract}

Key words: family, parenting style, parental behaviour, resilience.

\footnotetext{
* Silvia Barnová, DTI University, Department of School Pedagogy and Psychology, Dubnica nad Váhom, Slovakia; barnova@dti.sk

Viola Tamášová, DTI University, Department of School Pedagogy and Psychology, Dubnica nad Váhom, Slovakia; tamasova@dti.sk

Slávka Krásna, DTI University, Department of School Pedagogy and Psychology, Dubnica nad Váhom, Slovakia; krasna@dti.sk
} 


\section{Acta Educationis Generalis \\ volume 9, 2019, issue 2}

\section{Introduction}

Family background may be considered the basic indicator of children's development (Tamášová \& Šulganová, 2016). When mentioning family, all those who had a contented childhood and grew up in an emotionally warm environment, recall situations with their beloved ones. For the lucky ones, it is very difficult to imagine what adversity some children must face in their families and that those, who should help and support them, literally hinder their healthy development.

Every responsible parent realizes the importance of treating children with love and unconditional, but not boundless respect for their personality. Education in general is an ongoing process leading towards the healthy and complex development of an individual. It is a demanding process which requires a great deal of patience. Its mission is to bring up people with free, creative and critical thinking who are able to act independently, make meaningful decisions, solve problems constructively, and take full responsibility for their actions.

Parents should possess sufficient parental skills in order to ensure their children's healthy development. Provision of a stable family background characterized by love, understanding and support as well as of a sufficiently stimulating family environment can have a significant impact on the life trajectory of a child.

\section{Parenting styles}

As a result of education not respecting children's personalities applied in the past, many people have not learned to freely express their feelings. Children were taught not to show anger, to control themselves and not to cry. Unconditional obedience was often required and the children's opinions were rarely taken into account. Currently, an opposite trend can be observed, emancipation of children within their families is accentuated. In education, more emphasis is placed on such values as independence, freedom, and on the development of children's personalities, emotions and individuality. For parents, it is very difficult to find a healthy balance between strictness and providing children with freedom, which are equally important. In the process of upbringing, the consciously or unknowingly applied parenting style plays a significant role as family relationships can be considered among factors playing an important role during an individual's personality development and can have an impact on the emotional developments as well as the behaviour of children and youth (Ikhardt \& Szobiová, 2018). With different authors, we can find various, more or less detailed classifications of parenting styles. Among them, the following one is the most frequently cited in Slovak scholarly literature:

- Authoritarian parenting style - upbringing is based on strict following of rules with no exceptions, without accepting the views and needs of children. Children's lives are precisely organized; their independence is supressed 


\section{Acta Educationis Generalis \\ volume 9, 2019, issue 2}

and thus, their self-confidence is decreased. The authoritarian parenting style is related to underestimating own abilities and the children's performance at school may be below their study potential.

- Liberal parenting style - it is the opposite of the authoritarian style, but it can have a negative impact on the child as well. There is a lack of norms and restrictions, every wish of the child is fulfilled and the needs of other family members are neglected. There is a risk that these children will not be able to work in teams and will become individualistic.

- Neglecting parenting style - parents do not take care of their children properly, they are indifferent.

- Democratic parenting style - it is based on a partnership, where parents and children make decisions about family matters together and the needs of all family members are equally respected. Children learn to take the responsibility for their actions and develop their independence. Thus, the likelihood of an easier adaptation to the needs of others as well as the ability to compromise in the future is increased. The parents require following the established rules by children, but, at the same time, trust their judgment. Such a parent-child relationship is characterized by mutual trust, and therefore, parents possess much more information on where their children are, who they are with and what they are doing in their leisure time. This parenting style is generally considered optimal.

Biddulph uses a different classification:

- Abusive parenting style - parents harm their children verbally, and sometimes also physically, label them "losers"; or keep repeating that they will achieve nothing in their lives. Gradually, children identify themselves with their labels and they are suddenly not able to solve problems constructively, but they show anger and are aggressive. They do not gain enough respect, and so, they are not able to show respect to their environment.

- Conditional parenting style - the communication between the parents and their children is based on threats and giving conditions. In this case, there is a risk that the children will be too performance-focused and will have problems with building relationships.

- Indulgent parenting style - children are isolated from any kind of adversity, including sadness, failure, conflicts and demanding situations, although they need to gain own experiences, including disappointment. Children do not have an opportunity to develop their own coping strategies which they need in situations when their parents cannot protect them.

- Neglectful parenting style - parents are not much interested in their children and their development, their primary goal is to feed and dress them. There is a lack of emotional closeness. Children feel lonely, neglected and 


\section{Acta Educationis Generalis \\ volume 9, 2019, issue 2}

helpless, so they try to attract the attention of their environment by means of negative behaviour.

- The Assertively-Caring parenting style - parents lead their children towards independence (Biddulph, 2006).

Many authors, such as Masten and Coatsworth (1998), Steinberg et al. (2004) and Fontana (1997), consider "authoritative parenting" the optimal style of family education. Masten and Coatsworth (1998) found that it is related to positive academic achievement. This parenting style is characterised by the above authors as emotionally warm and supportive. Parents do not give absolute freedom to their children, but they monitor them with regards to their age and the actual context. In the family, the demands and expectations regarding acceptable behaviour are clearly defined and high, and manageable requirements on performance are placed on the children.

\section{Negative impacts on children's mental development}

Although it is stated in the Preamble to the Convention on the Rights of a Child that "the child, for the full and harmonious development of his or her personality, should grow up in a family environment, in an atmosphere of happiness, love and understanding" (Convention on the Rights of the Child, n.d.), it is not always so.

When the social environment makes it difficult for them to develop (such as in homes where abuse and violence occur), it is proven that social achievement and academic achievement are poorer, and the risk of substance abuse is increased (Zucker, 2008). Children growing up in such a family environment find themselves in demanding situations when, due to insufficient support, they are not able to cope with problems effectively, and they cannot choose socially acceptable strategies which could help them overcome adversity. Based on the results of the research carried out by Rae-Grant, Thomas, Offord and Boyle; Armstrong, Stroul and Boothroyd (in Ungar, 2005) state that risk factors inside the family represent the biggest threat to children as for psychiatric problems.

In order to cope with family problems, individuals typically choose from three forms of protective reactions - attack, escape (rash, chronic escapes, wandering, lying), and coping.

In scholarly literature, four basic types of adverse situations occurring in families can be found - stress, conflicts, frustration and deprivation.

\subsection{Busy parents}

Recently, our lives are getting faster and faster. Parents spend a lot of time working to ensure the best possible conditions for their families and to pay all the fees for their children's leisure-time activities as well as extra classes at school, not taking into account that the children are often not interested in them at all and are often overloaded. An increase in the number of dual career families 


\section{Acta Educationis Generalis \\ volume 9, 2019, issue 2}

can be observed and the time spent together with their children is slowly disappearing. The leisure time activities offered by various institutions cannot replace the joint family activities. In addition, it has a negative impact on children if they see their parents exhausted in the evenings, not to mention that such parents are nervous and often irritated. As a result, children may become insecure, have low self-confidence, may stop to trust their parents and take part in socially unacceptable activities.

The children of busy parents are often emotionally deprived due to the limited time spent with their parents and insufficient communication in the family. In adulthood, they are not always able to lead normal family lives as their parents are not optimal role models for them.

\subsection{Incomplete, disturbed, divorced and follow-up families}

Family stability influences children's behaviour and outcomes, academic performance and achievement, the development of social skills, and their emotional functioning. Children reared in safe and stable environments, can adapt better both in the short and long terms compared to children being exposed to harmful experiences (Harden, 2004). Growing up in incomplete, disturbed, divorced or follow-up families can be considered an adverse situation.

In incomplete families, either a parent or a child is missing (childless couples). Family education in incomplete families should not be significantly different from full families, only the situation is more demanding. The absence of a parent does not necessarily have to be reflected in the mental health of children, since difficult conditions do not necessarily imply bad conditions, although the roles of mothers and fathers are specific, complementary and, in a certain sense of meaning, irreplaceable. Such a situation requires an increased degree of attention and patience, and much more time spent together in order to compensate the child for the missing parent.

In Slovakia, approximately one quarter of children grow up in divorced families (Ondrejkovič \& Majerčíková, 2005), but not all of them suffer from divorce. When the conflict between parents is intense, chronic and overt, divorce is an effective release form the toxic home environment for children (Pedro-Carroll, 2001). Rutter (2005), based on the results of his research, states that a problematic process of separation of parents brings a risk for the child, whereas in the case of smooth separation, it does not have to be so. It is not the separation of parents itself that is decisive but the presence of a conflict between them.

Every child suffers when his/her parents quarrel and feels that the overall family climate is disturbed. Children want their parents to solve the problem between them. They try to attract their attention at all costs, even by negative or aggressive behaviour. The impact of a crisis situation may become visible as late as in the adulthood.

In cases when parents opt for separation or divorce, they often forget that living in separate households does not mean the end of the family, only its form 


\section{Acta Educationis Generalis \\ volume 9, 2019, issue 2}

changes. For the further development of children, it is important to preserve the existing family relationships. Children should feel safe and must be sure that they are loved by both parents. Experience shows, that only few couples are able to maintain positive relationships, on the contrary, they manipulate or use their children against their former partners. Thus, parents expose their children to stressful situations. Vlčková (2001) considers such treatment a psychiatric abuse. According to Pedro-Carroll (2001), divorce has an impact on children. She characterizes new circumstances as follows:

1. Divorce is not a single event but a series of transitions and family reorganizations that modify the lives and developmental context of children. Divorce is synonymous with change - a myriad of changes that range from emotional to economic, e.g., changes in family relationships, standard of living, neighbourhood, friends, remarriage, and sometimes even loss of a beloved pet.

2. The process of adjustment to these changes is stressful for families. However, it is important to note that family members are not affected uniformly by a divorce. What may be a positive life change or coping strategy for one family member is not necessarily beneficial for other family members. Children rarely wish for a divorce, so their reactions and adjustment processes are understandably often divergent from their parents.

3. Although the process of marital dissolution is surely stressful for children, there is substantial variation in their adjustment to divorce over time. However, most children experience considerable distress in the early stages. Sadness, anxiety, anger, resentment, confusion, guilt, fears for their future, loyalty conflicts, somatic symptoms and grieving for absent parents are frequent early reactions. The trajectory of children's long-term adjustment is shaped by a number of risk and protective factors.

As part of her research focused on the impact of divorce on children, the same author identified the following protective factors:

a) Individual factors: realistic appraisal of control; accurate attributions; active coping style; effective coping skills;

b) Family factors: protection from interparental conflict; psychological wellbeing of parents; solid, supportive parent-child relationships; authoritative parenting, household stability and structure;

c) Extra-familiar factors: supportive relationship with positive adult models, support network: family, school and community evidence-based preventive interventions; providing support and skills training (Pedro-Carroll, 2001).

The results of Pomrenke's (2007) qualitative research also confirmed that children from separated or divorced, high-conflict families need to have access to strong support within the family (step-parents, other family members) and external support systems (peers, teachers, other professionals) in order to cope 


\section{Acta Educationis Generalis \\ volume 9, 2019, issue 2}

with the unstable family environment. At the same time, the results show that children living in unstable families having at disposal such protective factors exhibited resilient characteristics. The author assumes that external support systems may supplement family strength.

Pomrenke's findings confirm that schools or their approach to students play a significant role in their students' ongoing development, especially in the case of those who do not have optimal conditions for their development at home. Schools can help students overcome the adversity that they have to face at home by means of providing a favourable school climate, effective curriculum and teachers' appropriate approach, i.e. by offering a wide range of protective factors.

The so-called follow-up families are created when one of the children's parents finds a new partner and gets married, i.e. the child gets a foster parent. Some children adapt to such a new situation easily, but others might have problems with coping with it and conflict situations occur between them and their step parents. Although there is a prejudice, that the relationship between children and their step-parents is usually negative, the above Pomrenke's qualitative research on children which previously lived in high conflict families, did not prove it. Many of the participating children had very good relationships with their stepparents.

\subsection{Loss and sadness}

People are confronted with a loss several times during their lives, including children. In their case, it can be the separation or divorce of parents, when their older sibling moves away, the whole family moves, children have to change their school, when someone close passes away or when their pet dies. Children lose their safety, feel helpless and desperate. Such a loss is accompanied with sadness which can result in trauma and cause anxiety. It can lead to closeness and isolation from the surrounding world, aggressive and socially not accepted behaviour, i.e. the inability or unwillingness to follow the generally accepted patterns of behaviour (Jandourek, 2001). The extent to which children can cope with loss and sadness depends on the level of their resilience and the available protective factors: their personality, family cohesion, school and community support, and the overall context in which they live. Mallon (as cited in Kyriaciou, 1996) distinguishes between three stages of grief: the initial stage of grief which is the stage of protest, the active phase characterized by confusion and the receding phase which is the stage of reorganization.

\subsection{CAN - Child Abuse and Neglect}

Domestic violence is a phenomenon that everyone condemns, yet, it is still a permanent social problem. In the society, there is a prejudice that domestic violence is typically present in families from lower social strata, alcoholics, drug addicts, etc., but it also occurs in well-placed families where both parents are 


\section{Acta Educationis Generalis \\ volume 9, 2019, issue 2}

educated and often have a high social status. As many authors agree, the common feature of risky parents is their lack of parental competencies.

Based on world statistics, Dunovský (1999) states that from 1 to $2 \%$ of children are abused or neglected. Nearly one half of them is exposed to multiple types of maltreatment (Harden, 2004). In some cases, children witness cruelty and violence in the family, or even become victims of it. Regardless the form of domestic violence, children adopt the observed patterns of behaviour which can later cause serious problems in their family lives and in upbringing their children; there is a likelihood of becoming a neglectful and abusive parent in the future. Such a phenomenon is referred to as deprivation cycle.

Vaníčková et al. (1995) define child abuse and neglect as any conscious or unconscious activity committed by a parent, educator or other person against a child, which results in damage to their health and healthy development. Abuse is intentional and has a regular character, although, the aggressors do not always realize what they are doing. It is usually a long-term process (as children often try to hide the problem or the adults around them do not believe them), for which misuse of physical, psychological and social power are characteristic (Ondrejkovič, 2001). Victims experience an inner conflict between trying to avoid pain on one hand, and maintaining a close relationship or contact with their parents on the other hand. Such a situation causes helplessness and frustration leading to emotional deprivation, psychosomatic problems and, in extreme causes, to the death of a child. The so-called Child-Abuse Syndrome increases the likelihood of adopting the role of a victim and being bullied at school as well.

Kopčanová (2002) distinguishes between four types of child abuse:

1. Physical abuse (e.g. fights): if it is not the case of a "clever" aggressor who does not leave a trace, it is easier to recognize than mental abuse. There are visible traces on the child's body - bruises, burns, frequent fractures, or the child does not develop appropriately to his/her age. Such a child is often tired and avoids physical contact with others.

2. Mental or emotional abuse (e.g. emotional extortion, constant humiliation, exposure to stress, pressure, rejection, and neglect) have an impact on the mental health of children. Mental abuse of children is also associated with eating disorders (especially in the case of girls) and suicide attempts.

3. CSA - Child Sexual Abuse, including both its contact, or non-contact (masturbation, watching films, collecting pictures, etc.) forms, is still a taboo in the society. Between one quarter and one-third of all cases of sexual abuse occur in households and is committed by the victim's family members. The most commonly abused children are those with insufficient self-confidence, the weak individuals who are not able to protect themselves. In addition to physical injuries, the mental health of children is negatively influenced, too. The Internet represents another source of risks for children as they may become used for the purposes of child 


\section{Acta Educationis Generalis \\ volume 9, 2019, issue 2}

pornography, not rarely by their own parents, relatives, well-known people, but also by strangers who somehow gain the trust of children, or offer some kind of reward to them.

4. Neglect - its symptoms of physical neglect are easy to recognize - the child is malnourished, frequently ill, his hygiene is neglected. In the case of emotional neglect, e.g. parents focus on themselves, their problems and own relationship and do not sufficiently communicate with their children or they do not spend enough time together.

\subsection{Victimless crime}

Victimless crime includes such negative social phenomena as gambling, drug addiction or prostitution. The individual does not harm others directly, but has a negative impact on the society as such, on the life of the individual him/herself as well as on everyone close to him/her.

The ecologies in which children are situated have the greatest influence on their formation. Parents are role model for their children, so it is likely that they imitate their behaviour and adopt their habits. If a child grows up in an environment where problems with substance abuse, gambling, or prostitution occur, there is a serious risk that the child will adjust the existing conditions and adopt such a way of life in the adulthood as well.

It should be highlighted that an increased probability does not mean a rule. Many children growing up in such an environment, due to their resilience and available external protective factors, become healthy and successful adults with a negative approach towards drugs and gambling. For these individuals, the motivation comes from the recognition and appreciation from their environment for being able to achieve success despite the exposure to various challenges, their efforts help them to take control over their lives and the world around them becomes more predictable for them. Utilizing success as a coping strategy may help them in the process of transition from a pathological to a healthy environment.

The situation of children living in toxic environments is made even more complicated by the fact that the primary problem is usually accompanied by a whole series of other problems such as delinquency, various forms of physical, emotional, and/or sexual abuse and neglect; repeated separation or the outright divorce of the parents; problematic behaviour of siblings etc.; and stressors increasing the risk of a negative impact on the child cumulate (Hall \& Webster, 2007).

The issues of alcoholic families were dealt with by Ruben (as cited in Hall \& Webster, 2007), who presented the rules operating in an alcoholic home. The basic rule in such households is not to talk about family problems and to limit communications with others outside the home in order to keep family secrets. Children growing up in such an environment are encouraged not to trust anyone and not to express their feelings openly, so it is not unusual that alcoholism in 


\section{Acta Educationis Generalis \\ volume 9, 2019, issue 2}

the family remain unnoticed for a long time. These children often lack the social skills necessary to create and maintain personal relationships, are relational, oversensitive to any kind criticism, and misinterpret what the communication partner tries telling them. The inability to cope with such adversity can eventually generate a great deal of anger (Hall \& Webster, 2007).

Another rule reported by Ruben is that children try to prevent conflicts and confrontations at all costs because they often result in their parents' unexpected aggression and subsequently lead to the children's punishment. Therefore, children try to escape and thus, do not have opportunities to learn effective problem-solving strategies. Escape as a strategy of coping is often insufficient as the conflict does not disappear, but by postponing its solution its intensity increases.

Zucker et al. (2008) point out that in the case of the children of alcoholics, the risk of antisocial behaviour is higher. The children of alcoholics are lower in sensibility than their classmates, often have poorer academic achievement, truancy problems, and are more aggressive than their schoolmates. There is also a higher risk of addictions. These children are more likely to drink alcohol in their adulthood, they will probably drink more than their peers, and the development of problems with alcohol may be faster. Having alcoholic parents increases the likelihood of a child's drinking through having alcohol available and accessible in the home, insufficient parental supervision, but, above all, genetic and socialization factors representing a risk to children's development, and we cannot forget to mention the prenatal alcohol exposure.

\subsection{Socially disadvantaged children}

Students' academic achievement, as stated by Montousse and Renouard (2005), closely correlates with their social backgrounds. Children from an intellectually stimulating environment are more likely to study longer and achieve better results than students from socially disadvantaged groups, who are often lagging behind in terms of cognition.

Children from a socially disadvantaged environment rarely have favourable learning conditions, their needs are frequently not satisfied which may lead to biological, emotional or social deprivation.

\section{Resilience}

In the case of families where negative parental behaviour occurs, resilience can be discussed on two levels - on the individual and the family level.

\subsection{Children's resilience}

Resilience is undoubtedly of a great importance in the life of an individual as it is a special kind of competence, "an individual's capacity to recover, adapt, and keep mental balance and normal functioning when exposed to significant adversity or a personal crisis, i.e. the sum of such attitudes, behaviour and 


\section{Acta Educationis Generalis \\ volume 9, 2019, issue 2}

external factors that help people adapt to changing conditions and meet new challenges" (Barnová \& Gabrhelová, 2017). Kaplan (as cited in McCubbin, 2001), in relation to posttraumatic growth, defines resilience as giving a chance to achieve levels of development that go beyond what would have been reached without stress.

Children's performance is determined by many endogenous and exogenous factors including the level of their resilience, the seriousness of adversity, the available protective factors and the adopted coping strategies. Petrulyté (2018) states that the more strengths they gain, the more positive their development is. This is emphasized by Tamášová and Barnová (2001), who distinguish between four basic types of reactions to significant adversity - tolerance to adversity, increased functioning, decline in functioning (hidden resilience), and failure.

The importance of resilience, fostering it and developing a wide range of coping strategies in the life of children exposed to cumulated risks was proven by Masten's (1997) research. Its results show that the performance of "competent children" with little adversity in their environments and resilient children exposed to very high levels of adversity was very similar as for the awareness self-worth, self-efficacy and mental health. What is more, resilient children sometimes perform even better as they learned how to manage stress, how to cope with adversity, or how to take an advantage from it, and so they can recover from traumatic experiences sooner and better compared with their less resilient peers.

\subsection{Family resilience}

There is always a chance to change the unfavorable conditions within the family environment, to take advantage of crisis situations and to introduce changes that will improve the family members' quality of life. Families, similarly to individuals, apply various coping strategies to deal with adversity and to maintain their functioning. In the case of family resilience, not the individual family members, but the family as a whole and its scheme of its functioning are considered.

A family crisis can be defined as a situation characterized by a long-term disruption, disorganization, or shortcomings in the family social system. According to McCubbin and McCubbin (as cited in Ungar, 2005), the ability of a family to maintain its functionality or to recover and transform, i.e. to achieve balance and harmony, depends on the effectiveness of the six resilience related key competencies - managing the accumulation and reduction of coexisting or persistent historical stressors and pressure; mobilization of the strengths and individual capabilities of its members, as well as exploitation of the strengths and abilities of the group as a whole (restoring, and reinforcing the strengths that may have been weakened or damaged under the influence of trauma; creation and implementation of new patterns of functioning, changing and stabilizing the existing ones, and ensuring the continuity of new and preserved patterns; and to 


\section{Acta Educationis Generalis \\ volume 9, 2019, issue 2}

maintain emotional stability); adoption of the strengths of the community and its resources in order to achieve harmony with the community; minimizing the conflicts and maximizing the consistency between the family schema and the institutionalized forms of behaviour, and thus, promoting the feeling of manageability, clarity and meaningfulness; using a positive approach to problem solving and the application of the adopted coping strategies; sharing meanings and behavioural standards that are in line with the family scheme.

\section{Conclusion}

Negative parental behaviour represents a significant risk factor in children's lives as they, due to their age and lack of experiences, form a vulnerable social group. Therefore, in order to overcome adversity without serious harm, their resilience must be promoted and the repertoire of coping strategies should be continuously widened. On the other hand, it must be highlighted that resilience is not unlimited, automatic or universal, and certainly does not mean that one is invulnerable. Gabarin (as cited in Ungar, 2005) points out that every individual has certain limits, when exceeding them, it comes to failure. The same applies to the already adopted coping strategies - they are culturally and situationally related and definitely not universal.

Professionals should be aware that children at risk need help and support; and especially teachers should realize that schools represent an important protective factor in children's lives. Unfortunately, the school building is often the only place where children feel safe and secure.

\section{Acknowledgements}

The authors gratefully acknowledge the contribution of the KEGA Grant Agency of the Slovak Republic under the KEGA Project 004DTI-4/2018 "Model that will support the development of emotional intelligence of pupils at secondary vocational schools."

\section{References}

Barnová, S., \& Gabrhelová, G. (2017). Resilience in Schools. Karlsruhe: SteCon.

Biddulph, S. (2006). Tajemství výchovy štastných dètí (2nd edition). Praha: Portál, 2006.

Convention on the Rights of the Child. Retrieved from http://www.ohchr.org/ EN/ProfessionalInterest/Pages/CRC.aspx

Dunovský, J. et al. (1999). Sociálni pediatrie. Praha: Grada.

Fontana, D. (1997). Psychologie ve školní praxi. Praha: Portál.

Hall, C. W., \& Webster, R. E. (2007). Risk Factors among Adult Children of Alcoholics. International Journal of Behavioral Consultation and Therapy, 3(4), 494-511. 
Harden, B. J. (2004). Safety and Stability for Foster Children: A Developmental Perspective. The Future of Children, 14(1), 30-47. Retrieved from http://files.eric.ed.gov/fulltext/EJ796432.pdf

Ikhardt, P., \& Szobiová, E. (2018). Štýly rodičovstva a mentálne zdravie adolescentov. In E. Gajdošová, M. Madro, \& M. Valihorová (Eds.), Duševné zdravie a wellbeing virtuálnej generácie (pp. 64-78). Bratislava: IPčko.

Jandourek, J. (2001). Sociologický slovnik. Praha: Portál.

Kopčanová, D. (2002). Ochrana pred týraním a zneužívaním detí v domácom a školskom prostredí. In Poradca pri vedení školy 2 (pp. 1-28). Bratislava: RAABE.

Kyriacou, C. (1996). Klíčové dovednosti učitele. Praha: Portál.

Masten, A. S. (1997). Resilience in Children at-Risk. Research/Practice Newsletter, 5(1). Retrieved from http://cehd.umn.edu/CAREI/Reports/ Rpractice/Spring97/resilience.html

Masten, A. S., \& Coatsworth, J. D. (1998). The Development of Competence in Favorable and Unfavorable Environments. American Psychologist, 53(2), 205-220.

McCubbin, L. (2001). Challenges to the Definition of Resilience. San Francisco, CA. Retrieved from http://files.eric.ed.gov/fulltext/ED458498.pdf

Montoussé, M., \& Renouard, G. (2005). Přehled sociologie. Praha: Portál.

Ondrejkovič, P. (2001). Sociálna patológia (2nd revised edition). Bratislava: VEDA.

Ondrejkovič, P., \& Majerčíková, J. (2005). Zmeny v spoločnosti a zmeny v rodine - kontinuita a zmena. Sociológia, 38(1), 5-30.

Pedro-Carroll, J. (2001). The Promotion of Wellness in Children and Families: Challenges and Opportunities. San Francisco, CA. Retrieved from http://files.eric.ed.gov/fulltext/ED458502.pdf

Petrulyté, A. (2018). Adolescents' social emotional health and empathy from the perspective of positive psychology. In E. Gajdošová, M. Madro, \& M. Valihorová (Eds.), Duševné zdravie a wellbeing virtuálnej generácie (pp. 20-31). Bratislava: IPčko.

Pomrenke, M. (2007). Using Grounded Theory to Understand Resiliency in PreTeen Children of High-Conflict Families. The Qualitative Report, 12(3), 356-374. Retrieved from http://files.eric.ed.gov/fulltext/EJ800194.pdf

Rutter, M. (2005). Environmentally Mediated Risks for Psychopathology: Research Strategies and Findings. Journal of the American Academy of Child \& Adolescent Psychiatry, 44(1), 3-18.

Steinberg, L. et al. (2004). The Study of Developmental Psychopathology in Adolescents. In D. Cicchetti (Ed)., Handbook of Developmental Psychopathology. New York: John Wiley \& Sons, 2004. Retrieved from https://www.nyas.org/ebriefreps/ebrief/000219/archives/Developmental Handbook.pdf 


\section{Acta Educationis Generalis \\ volume 9, 2019, issue 2}

Tamášová, V., \& Barnová, S. (2011). School climate as the determinant of the relationship between the level of students' resilience and school satisfaction. Acta Technologica Dubnicae, 1(1), 19-37. https://doi.org/10.1515/atd-2015-0037

Tamášová, V., \& Šulganová, Z. (2016). Promotion of Family Reading in the Context of Children's Early Reading Literacy Development. Acta Technologica Dubnicae, 6(2), 9-38. https://doi.org/10.1515/atd-2016-0009

Ungar, M. (Ed.): Handbook for Working with Children and Youth. Thousand Oaks: SAGE.

Vaníčková, E. et al. (1995). Násilí v rodině. Praha: Karolinum.

Vlčková, M. (2001). Týrané diet’a. Bratislava: Univerzita Komenského v Bratislave.

Zucker, R. A. et al. (2008). Early Developmental Processes and the Continuity of Risk for Underage Drinking and Problem Drinking. Pediatrics, 121, S252-S272. 